\title{
Metisilin dirençli Staphylococcus aureus (MRSA) enfeksiyonu için hızlı uyarı sistemi
}

\author{
Ayfer Cetin $^{1}$ (D), Ahmet Koluman*1 (iD
}

${ }^{1}$ Pamukkale University, Faculty of Technology, Biomedical Engineering Department, 20160, Denizli, Turkey

$\ddot{O} z$

Bu çalışma, farklı kontaminasyon seviyelerindeki MRSA’nın tespit süresi üzerine tasarlanmıştır ve çalışmada fırsatçı patojen hastane enfeksiyonları arasında yer alan MRSA tespitine yönelik hızlı bir tespit sistemi oluşturulmuştur. MRSA tespiti yüksek ve orta yoğunluklu üremenin olduğu sıvı besiyerlerinde sekiz saatin sonunda gerçekleştirilmiştir. Tüm yoğunluklardaki üremenin olduğu sıvı besiyerlerindeki MRSA tespiti ise on saatin sonunda gerçekleştirilmiştir. Eppendorf’lar deneyden 24 saat sonra tamamen renk değiştirmiştir. Çalışmada kalitatif ve kantitatif sonuçlara bu tespit sistemiyle ulaşılmıştır. RGB sensörü kalitatif sonuç tespitinde pozitif sonuçta yeşil yanarken negatif sonuçta ise sensörün kırmızı yandığı gözlemlenmiştir. Sonuçların kantitatif verileri Arduino Programı'nın Seriport ekranı aracılığıyla izlenmiştir. Çalışmada tasarısı yapılan sistemin MRSA tespiti hızlı, spesifik, tutarlı, düşük maliyetli, tecrübeli teknik eleman gerektirmeyen ve aynı zamanda PCR testi yapılmadan önce tarama testi olarak kullanılabilecek bir sistem olarak kabul edilmiştir.

Anahtar kelimeler: Arduino Programı; biyosensör; hızlı tespit yöntemi; metisilin dirençli Staphylococcus aureus (MRSA)

\section{A rapid alert system for methicillin resistant Staphylococcus aureus (MRSA) infection}

\begin{abstract}
This study was designed on the detection time of MRSA at different contamination levels and in this study, a rapid alert system was established for the detection of MRSA, which is among the opportunistic pathogen nosocomial infections. MRSA detection was realized in broths with high and moderate growth at the end of eight hours. However, MRSA detection in broths with growth at all densities was performed after ten hours. After 24 hours of the experiment, colors of the Eppendorf's were completely changed. In the study, qualitative and quantitative results were achieved with this detection system. It was observed that the RGB sensor was lit in green for the positive result in the qualitative result detection, while the sensor was lit red for the negative result. The quantitative data of the results were monitored through the Seriport screen of the Arduino Program. The MRSA detection of the system designed in the study was accepted as a fast, specific, consistent, cost-effective and non-experienced technical staff required system that can be used as a screening test before the PCR test is performed.
\end{abstract}

Keywords: Arduino Program; biosensor; methicillin resistant Staphylococcus aureus (MRSA); rapid detection method

\footnotetext{
* Sorumlu yazar.

E-mail: akoluman@pau.edu.tr (A. Koluman).

https://doi.org/10.51753/flsrt.990547 Yazar katkılar1

Geliș tarihi 03 Eylül 2021; Kabul tarihi 22 Ekim 2021

Çevrimiçi yayın 15 Aralık 2021

2718-062X (C) 2021 This is an open access article published by Dergipark under the CC BY license. 


\section{Giriş}

Hayvanların ve insanların üriner sistem, yumuşak doku, deri ve kemik yapılarında Staphylococcus cinsinde siniflandırılan bakterilerin enfeksiyonlara sebep olduğu belirlenmiştir. Staphylococcus gram pozitif bir bakteri olup, yaşam alanlarımızda da oldukça yaygındır (Appelbaum 2006; Cadena ve ark., 2016). Hastane enfeksiyonu (HE) olarak tabir edilen nozokomiyal enfeksiyonların en önemli nedenlerinden biri olduğu kabul edilmektedir.

Hastane koşullarında bulaşan mikroorganizma kaynaklı oluşan enfeksiyonlar "Hastane Enfeksiyonu" olarak adlandırılmaktadır. Enfeksiyonların sebep olduğu hastalıklar göz önüne alındığında, bu hastalıkların en fazla hastane enfeksiyonlarından kaynaklandığ 1 belirlenmiştir. Centers for Disease Control and Prevention (CDC) hastane enfeksiyonunu hastanın hastaneye yattığı anda inkübasyon süresinde olmadığ enfeksiyon bulguları taşımadığı ve hastane ortamında enfekte olduğu durum olarak tanımlamıştır. Hastane enfeksiyonlarının genellikle hastanın hastane yatışından 48-72 saat sonrasında ortaya çıkabileceği, ya da hastanın taburcu olmasından 10 gün sonrasına kadar belirlenebileceği bildirilmiştir (Vincent 2003; Sousa ve ark., 2011).

Küresel olarak bakıldığında, hastane enfeksiyonlarının hasta kaybına yönelik problem teşkil ettiği belirlenmiştir. Gelişmiş ülkelerde, hastanedeki hastaların \%5-10'unda hastane enfeksiyonu oluşabilmektedir. Bu oran gelişmemiş ülkelerde ise \%25'e kadar çıkabilmektedir (Fridkin ve ark., 1997).

Hastane enfeksiyonları sadece hastayı değil, refakatçi ve sağlık çalışanlarını da etkiler. Morbidite ve mortalitede artış, yaşam kalitesinde düşüş, maliyet ve üretkenlik kaybı, hastanede kalış süresinde uzama gibi birçok sorun hastane enfeksiyonu ile ortaya çıkmaktadır (Fridkin ve ark., 1997; Vincent, 2003).

Vakaların çoğunun tedavisi kolaydır. Ancak vakaların bir kısmında osteomiyelit, toksik şok sendromu, bakteriyemi, septik artrit ve endokardit gibi bazı invaziv enfeksiyonlar tetiklenebilir ve ortaya çıkabilecek komplikasyonlar hastanın yatarak tedavi olmasına sebep olabilir. Vücutta ortaya çıkan patojen enfeksiyonlar antibiyotik tedavisiyle giderilebilir (Appelbaum, 2006; Becker ve ark., 2015; Cadena ve ark., 2016).

Staphylococcus aureus penisilin direncinin penisilinin tedavide kullanılmaya başlanmasıyla geliştiği belirlenmiştir. Metisilin gibi penisilinaza dirençli antibiyotikler penisilin direncini yenmek üzere kullanılmaya başlansa da, S. aureus suşlarında metisiline karşı direnç ortaya çıkmıştır. Raporlara bakıldığında, metisilin direncine bağlı olarak Staphylococcus enfeksiyonlarının tedavisinde beta laktam antibiyotiklerinin kullanılamadığı anlaşılmaktadır. Glikopeptid olan vankomisin MRSA (metisilin dirençli Staphylococcus aureus) enfeksiyonlarının tedavisinde uygulanılmıştır. 2002 yılı itibariyle $S$. aureus vankomisine direnç göstermeye başlamıştır. Bu bilgiler ışığında Staphylococcus enfeksiyonları tedavisinin daha da güçleştiği bildirilmiştir (Weems, 2001; Becker ve ark., 2015).

MRSA enfeksiyonlarında çoklu antibiyotik direncinin oluşması tedavi süresini uzatmaktadır. MRSA enfeksiyonu genellikle hastane ortamında yayılmaktadır. Hastalar veya sağlık çalışanları MRSA enfeksiyonunu hastane ortamına taşımaktadırlar. MRSA enfeksiyonuna sebep olarak, kişinin hastanede yatması, hastayla temasının olması, ya da kronik hastalık öyküsü riski arttırmaktadır (Weems, 2001).

Hastane ortamında MRSA mücadelesinde tedavi sürecinin hemen başlanması bu tür nedenlerden kaynaklı önemli bir adım oluşturmaktadır. Erken tespit ile MRSA enfeksiyonunda tedavinin hemen başlatılması, insidansta da azalma yaratmaktadır (Hidron ve ark., 2005).

$\mathrm{Bu}$ çalışmada, MRSA için hızlı tespit sisteminin geliştirilmesi amaçlanmıştır. MRSA taramasına yönelik besiyeri kullanılan kültüre dayalı yöntemlerin iki ve dört gün arasında sonuçlandığı bilinmektedir (Cadena ve ark., 2016). Bu süre uzun olduğundan, kontrole yönelik bulunacak önlemler gecikmektedir. Bu çalışma kapsamında bakterilerin gelişme düzeyleri metisilin içeren özel besi ortamlarında gözlenmiştir. Veriler yardımıyla yapılan hızlı tespit sistem optimizasyonunun ardından, söz konusu sistem içerisinde hastane örneklerinin analiz etmek üzere bir sistem düzeneği kurulmuştur.

\section{Gereç ve yöntemler}

Önceden hazırlanan BHI (Brain Hearth Infusion) brothun içine S. aureus (ATCC 29213) ekilerek üretilmiş BP (Baird Parker) agardan tek koloni edinilerek pasajlama yapılmış, üreme için $37^{\circ} \mathrm{C}$ etüvde 24 saat bekletilmiştir. BHI besi ortamına pasajlanan tüplerden mevcut zenginleştirmeden Şekil 1'de gösterilen seri dilüsyonlar yapılarak suşun logaritmik seviyesi tespit edilmiştir. Ekimler yirmi dört saat etüvde bekletildikten sonra, sayılmak üzere siyah zeminde ters olarak yerleştirilmiş, aynı numaralar altlı üstlü ayarlanmış ve koloniler sayılmıştır. Farklı şeker içeren tüpler önceden hazırlanmış bu tüplere pasajlama işlemi yapıldıktan sonra etüvde inkübasyona bırakılmıştır. Bu amaçla kullanılan şekerler ayrı ayrı hazırlanmış olup ayrıntılı bilgi aşağıda verilmiştir;

- $\% 1$ glikoz (Sigma G8270-100G), galaktoz (Sigma G0750100G), fruktoz (Sigma F0127-100G)

- $\% 2$ glikoz, galaktoz, fruktoz

- $\% 3$ glikoz, galaktoz, fruktoz

Toplam 9 grup oluşturulmuştur.

Öncelikle $\% 1, \% 2$ ve $\% 3$ oranında fruktoz içeren sekizer adet peptonlu su hazırlanmıştır. Seri dilüsyonlar yapılmıştır. Laminar kabinde yüzdelik oranlar için 16 tane PCA çift sıralı olacak şekilde sekiz sulandırma seviyesine kadar numaralandırılmış ve dizilmiştir.

İlk petriye ekim yapılmak için bir numaralı \%1 fruktoz solüsyonundan 100 mikrolitre alınmıştır. Daha sonra 100 mikrolitre daha alını 2. sıradaki 1 numaralı petriye ekim yapılmıştır. Her numara için işlem tekrarlanmıştır. Bu işlemin tamam1 $\% 2$ fruktoz, $\% 3$ fruktoz, $\% 1$ galaktoz, $\% 2$ galaktoz, $\% 3$ galaktoz, \%1 glikoz, $\% 2$ glikoz ve $\% 3$ glikoz şeker testleri için ayrı ayrı yapılmıştır.

Belirlenen uygun şeker karışımına renk indikatörü eklenmiştir. İçerik $100 \mathrm{ml}$ distile su için $\% 0,33$ glikoz, $\% 0,33$ fruktoz, 3,7 gr BHI, \%0,33 galaktoz, 0,01 gr Fenol Red veya Brom Creosol Purple olarak belirlenmiştir. Homojenizasyonu takiben Eppendorf'lara mikroorganizmalar eklenerek etüvde inkübasyona bırakılmıştır.

$\mathrm{Bu}$ amaçla sekiz farklı mikroorganizma hazırlanan broth ortamına konulmuştur. Bakteriler $37{ }^{\circ}{ }^{\circ}$ 'de inkübasyona bırakılmışlardır ve bakterilerin 2 saatte bir sistemden ölçümü alınmıştır. Seçilen bakteriler aşağıdaki şekildedir; Enterococcus faecalis ATCC 29212, Pseudomonas aeruginosa ATCC 24853, Escherichia coli ATCC 25922, S. aureus ATCC 29213, Staphylococcus epidemidis ATCC 12228, Bacillus subtilis ATCC 6633, Listeria monocytogenes ATCC 19115 ve Proteus mirabilis ATCC 1245. 


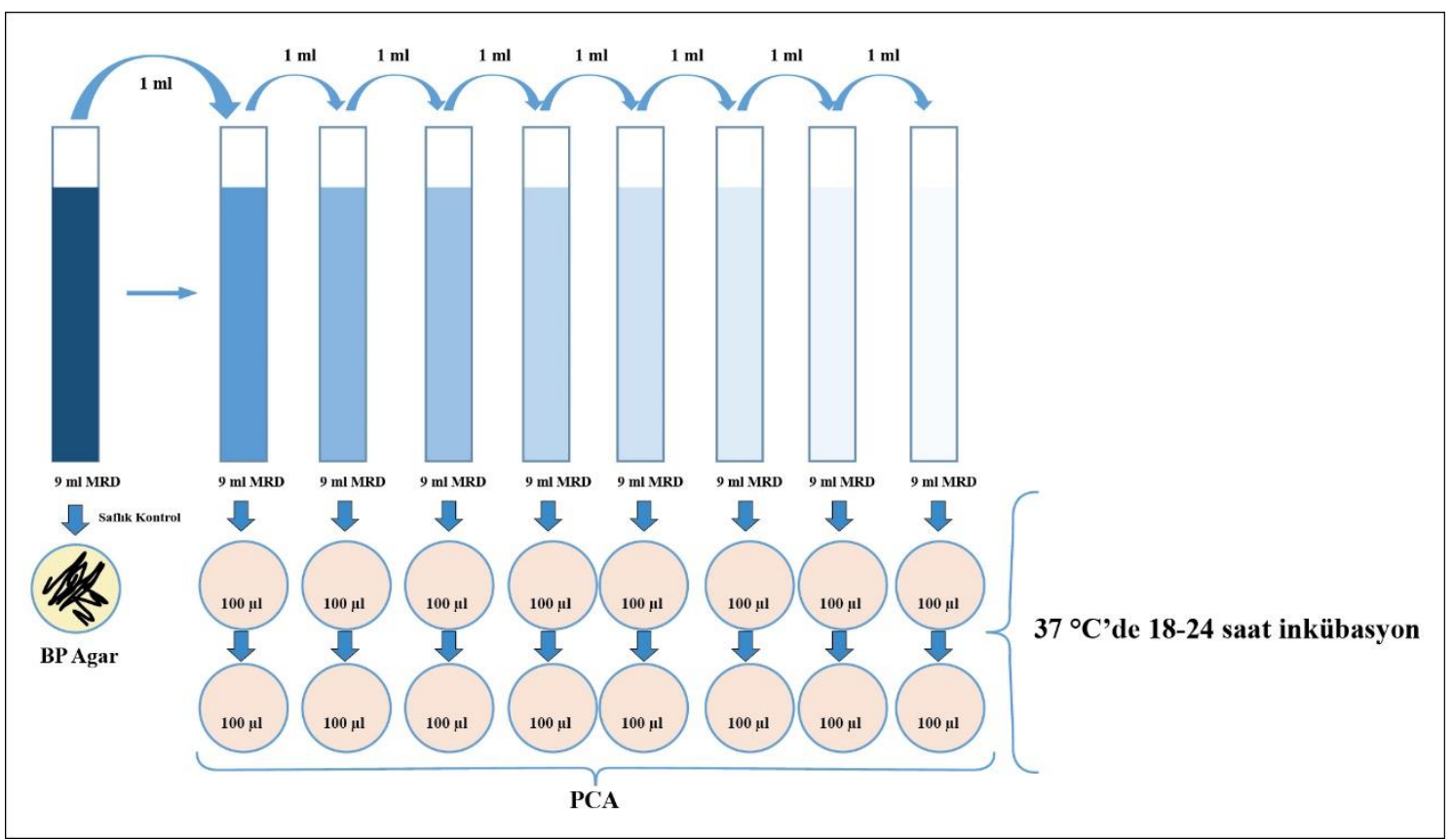

Şekil 1. Seri dilüsyonlar ve suşun gücünün belirlenmesi.

\subsection{Optik donanımın tasarımı ve programlanmast}

Şekil 2’ de devre bağlantıları görülmektedir.

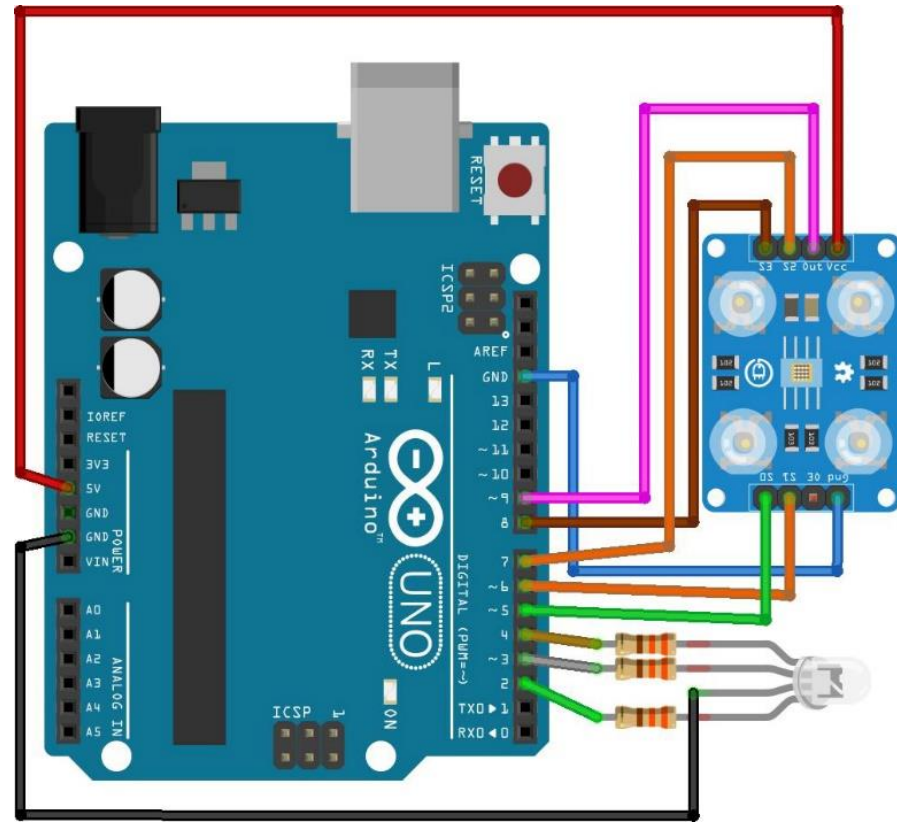

Şekil 2. Devrenin şeması.

Çalıșmadaki TCS3200 sensörü, bir frekans-akım dönüştürücüsü ve fotodiyotlar sayesinde renklerde ayırım oluşturur. Sensör, yansıyan ışığın şiddetiyle orantılı bir frekansta kare dalga üretir ve bu kare dalga kullanılarak veriler alınır. RGB ledinin çalışma prensibi aşağıdaki şekildedir. Pozitif ucuna $5 \mathrm{~V}$ bağlanınca mavi, kırmızı ve yeşil uçlarından yakmak istediğimizin yolu nötr ile tamamlanır. Böylece + kutbundan nötre doğru giden elektronların yolları tamamlanır ve nötr bağlanan led yanar.

Ölçüler kumpas kullanarak alınıp kutu tasarımı Solid Works ile yapılmıştır. Kutu tasarlanıp 3D yazıcı ile bastırılmıştır. Elde edilen ölçümler aşağıda verilmiştir.
Kutu: 70x70x70 mm

Pencere: $24,21 \times 31,04 \times 12,90 \mathrm{~mm}$

Orta bölüm: $62 \times 4 \times 38 \mathrm{~mm}$

Orta Kısıma yerleşecek parça 66x66 mm

Eppendorf deliği: $11,50 \mathrm{~mm}$

Kapak Boyu: 70,50x70,50 mm

Kapak Alt Kisım: 65,85x65,85 mm

Kutu ölçüleri Şekil 3’te gösterilmiştir.
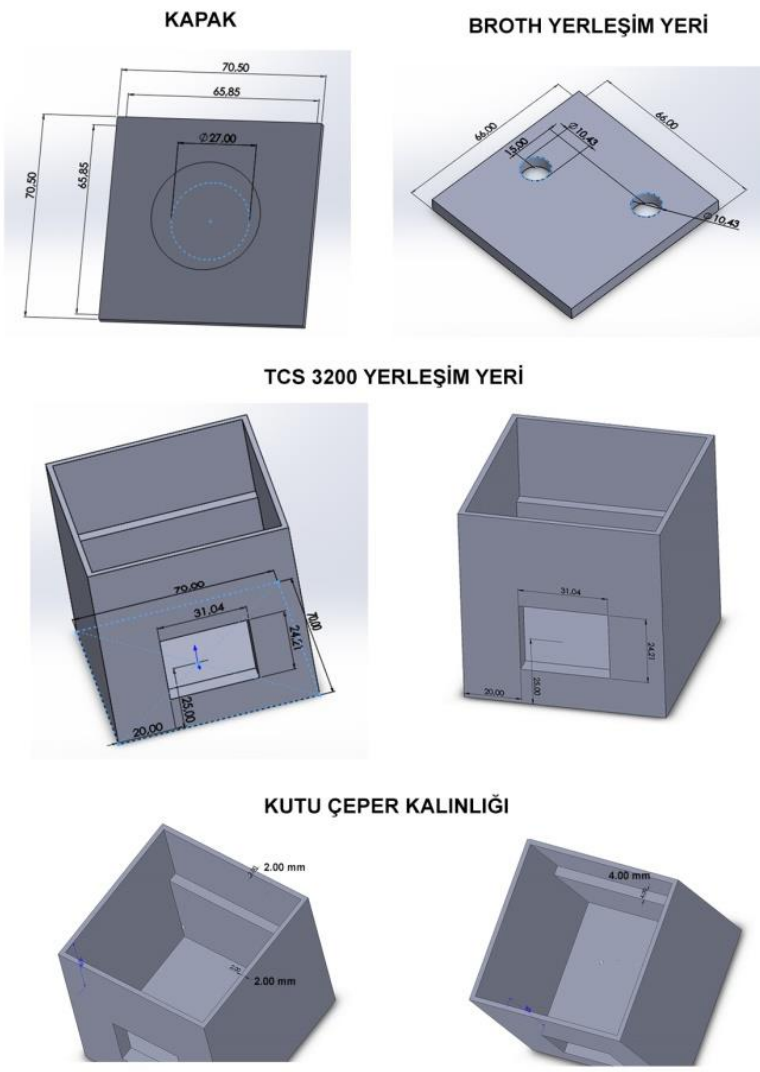

Şekil 3. Solid Works'te kutu çizimi. 
ISO 13485 standardına uygun bir şekilde Validasyon işlemi yapılmıştır. Broth tasarlanıp gerekli hazırlıklardan sonra 4 adet Eppendorf'a alınmıştır. Broth içine damlalar şeklinde eklenen $\mathrm{HCl}$ ile renk skalası oluşturulmuştur. Elde edilen renkler birbiri arkasından sistemde test edilmiştir. Ölçüm sonuçlarına göre, RGB sensöründen ve Arduino Seriport ekranından alınan sonuçlar tutarlı ve doğrudur. Şekil 4'te validasyon işleminde kullanılan renkler verilmiştir.

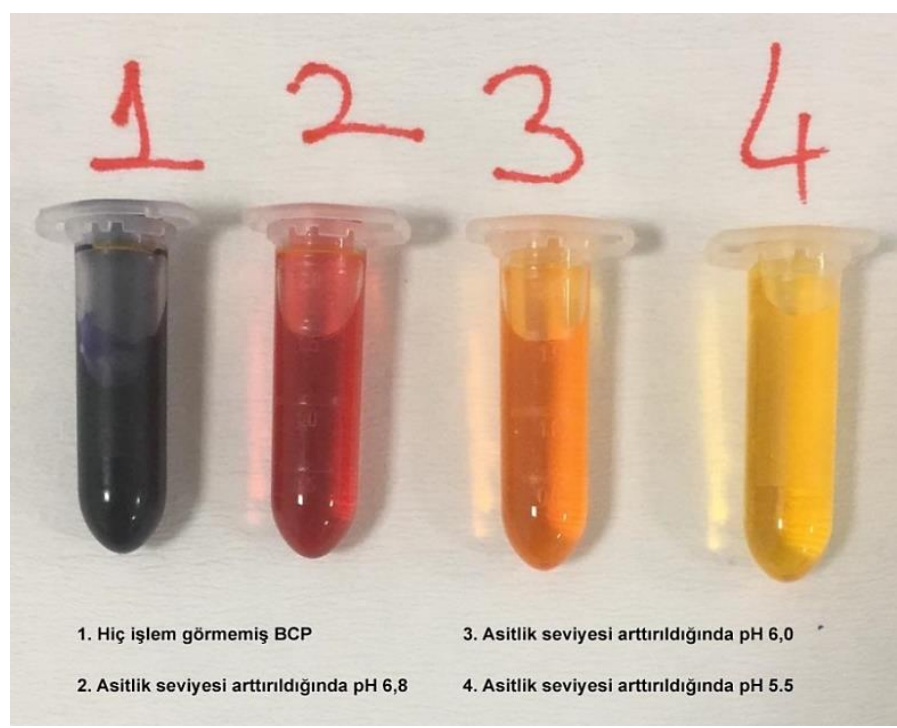

Şekil 4. Renk skalası.

1 numaralı Eppendorf ölçümünde bakterisine rastlanmamıştır. 1 numaraya sahip örnek kutuya koyulup ölçümü alındığında, RGB sensörü kırmızıdır ve Seriport ekranında "MRSA TESPITT EDİLEMEDİ" yazısı belirir. Sonuçlar Şekil 5'de gösterilmektedir.

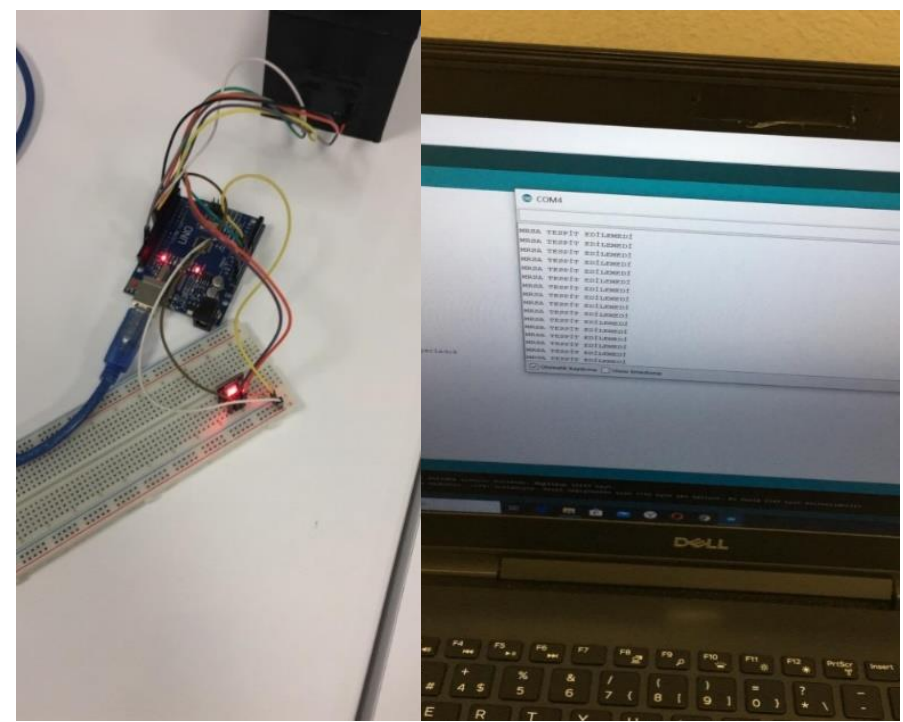

Şekil 5. Bakterisiz renk skalasında sistem cevabı.

İki numaraya sahip Eppendorf örneğinde düşük yoğunluğa sahip MRSA dönüşüm rengindedir. Kutuya konulduğunda RGB sensörü yeşil yanmış ve Seriport ekranında "MRSA TESPİT EDİLDİ. LÜTFEN KLASIK KÜLTÜR YÖNTEMİ İLE DOĞRULAYINIZ" yazısı görülmüştür. Sisteme ait sonuçlar Şekil 6'da verilmiştir.

Üç numarada orta yoğunluklu MRSA renk değişimindeyken teste alınmış, RGB sensörü yeşil Seriport ekranında "MRSA POZITIIF. LÜTFEN KLASİK KÜLTÜR YÖNTEMİ İLE DOĞRULAYINIZ" yazısı belirmiştir.

Dört numarada yüksek yoğunluklu MRSA içermektedir. Dört numara test edildiğinde RGB sensörü yeşil Seriport ekranında "MRSA POZITTIF. LÜTFEN KLASİK KÜLTÜR YÖNTEMİ İLE DOĞRULAYINIZ” uyarısı gözlemlenmiştir.

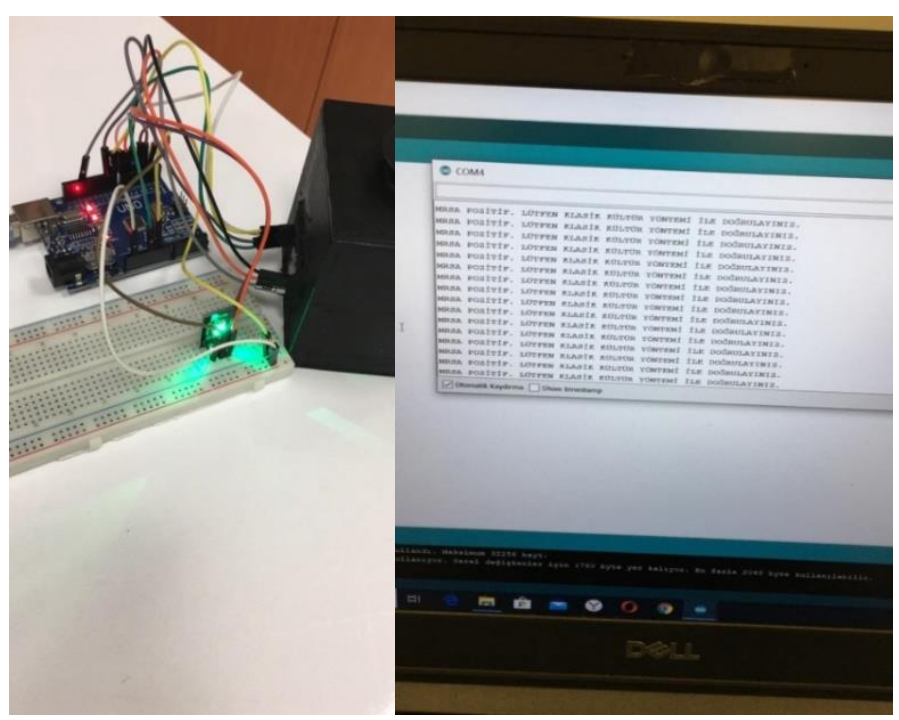

Şekil 6. Bakterinin düşük yoğunlukta olduğu renk skalasında sistem cevab1.

\subsection{Verifikasyon}

Broth hazirlandiktan sonra 6 adet Eppendorf'a dağıtılmıştır. Eppendorf'lar yoğunluklarına göre düşük, orta, yüksek yoğunluklu olarak 2'şerli olarak sınıflandırılmıştır. Brothlara bakteri bulaştırma oranları Tablo 1'de bulunmaktadır.

Tablo 1

Brothlara bakteri bulaştırma düzeyleri.

\begin{tabular}{ccc}
\hline $\begin{array}{c}\text { Bulaştırma } \\
\text { Düzeyi }\end{array}$ & $\begin{array}{c}\text { Koloni Oluşturan } \\
\text { Birim Sayısı }\end{array}$ & $\begin{array}{c}\text { Logaritmik Bulaştırma } \\
\text { Düzeyi (Kob/mL) }\end{array}$ \\
\hline Düşük & 20 & 1,3 \\
Orta & 300 & 2,47 \\
Yüksek & 1000 & 3 \\
\hline
\end{tabular}

Brothlar daha sonra $37{ }^{\circ} \mathrm{C}$ 'de etüvde üremeleri için inkübasyona bırakılmıştır. Renk değişimi İki saatte bir ölçülmüş ve MRSA'nın bulaştırılmış tespiti yapılmıştır. Deney sabah 9:00'da başlamış, deneyin ölçümleri ise 11:00, 13:00, 15:00, 17:00, 19:00, 21:00 ve 24 saatin sonunda ertesi gün 9:00'da alınmıştır.

\section{Bulgular}

Bu çalışmanın amacı S. aureus özellikle MRSA için hızlı tespite yönelik bir sistem oluşturulmasıdır.

\subsection{Sayımın yapılması}

Sayımlar yayma plak tekniği kullanılarak seri dilüsyonlar aracılığıyla yapılmıştır. 24 saatin sonunda ekimler etüvden alınarak, sayım için siyah zemin üzerine ters bir şekilde ve aynı numaralar altlı üstlü getirilerek yerleştirilmiştir.

Arkasından koloniler sayılmıştır. Sayım sonucu Tablo 2'de verilmiştir. 
Tablo 2

Bakteri cinsi ve enerji kaynağına göre tespit süreleri sonuç özeti.

\begin{tabular}{|c|c|c|c|c|c|}
\hline Kullanılan Şeker & $\begin{array}{c}\text { Eklenen Şeker } \\
\text { Yüzdesi }\end{array}$ & $\begin{array}{c}\text { Ekim Sonuçları } \\
\log _{10} \mathrm{kob} / \mathrm{mL}\end{array}$ & & Zaman & \\
\hline \multirow{7}{*}{ Glikoz } & & & 2. Saat & 4. Saat & 6. Saat \\
\hline & $1 \%$ & 2,903 & 5,361 & 5,361 & 7,602 \\
\hline & $1 \%$ & 2,903 & 5,278 & 5,447 & 7,602 \\
\hline & $2 \%$ & 2,903 & 5,954 & 6,301 & 7,903 \\
\hline & $2 \%$ & 2,903 & 5,602 & 6,301 & 7,903 \\
\hline & $3 \%$ & 2,903 & 5,361 & 6,301 & 7,903 \\
\hline & $3 \%$ & 2,903 & 5,278 & 6,301 & 7,778 \\
\hline \multirow{6}{*}{ Fruktoz } & $1 \%$ & 2,903 & 3,146 & 5,301 & 6,698 \\
\hline & $1 \%$ & 2,903 & 3,146 & 5,301 & 6,602 \\
\hline & $2 \%$ & 2,903 & 3,973 & 5,698 & 6,301 \\
\hline & $2 \%$ & 2,903 & 3,792 & 5,301 & 6,176 \\
\hline & $3 \%$ & 2,903 & 3,778 & 5,602 & 6,079 \\
\hline & $3 \%$ & 2,903 & 3,778 & 5,602 & 6,204 \\
\hline \multirow{6}{*}{ Galaktoz } & $1 \%$ & 2,903 & 5,903 & 5,778 & 6,477 \\
\hline & $1 \%$ & 2,903 & 5,778 & 5,698 & 6,602 \\
\hline & $2 \%$ & 2,903 & 5,477 & 5,602 & 6,903 \\
\hline & $2 \%$ & 2,903 & 5,602 & 5,301 & 6,778 \\
\hline & $3 \%$ & 2,903 & 5,079 & 5,778 & 6,698 \\
\hline & $3 \%$ & 2,903 & 5,954 & 5,845 & 6,602 \\
\hline
\end{tabular}

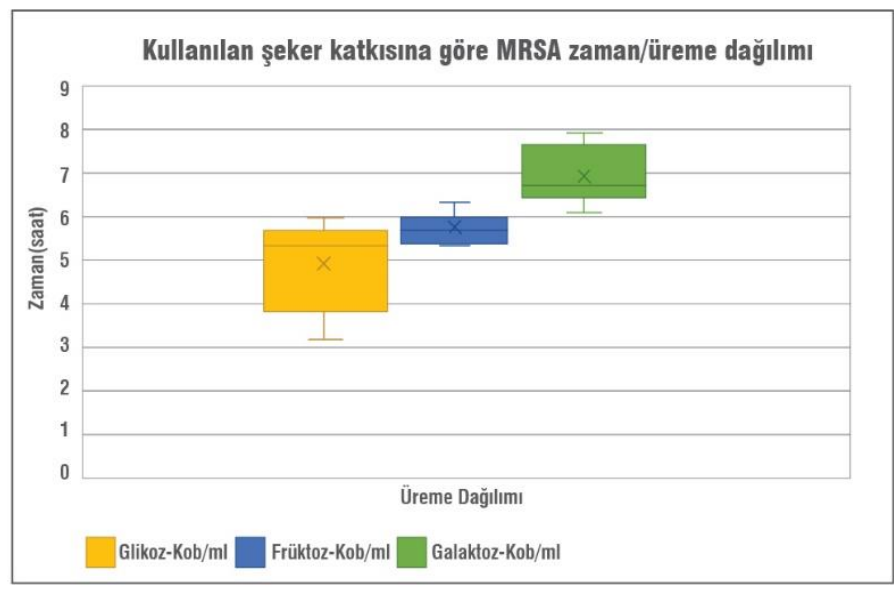

Şekil 7. Kullanılan şeker yüzdesine göre standart sapma grafiği.

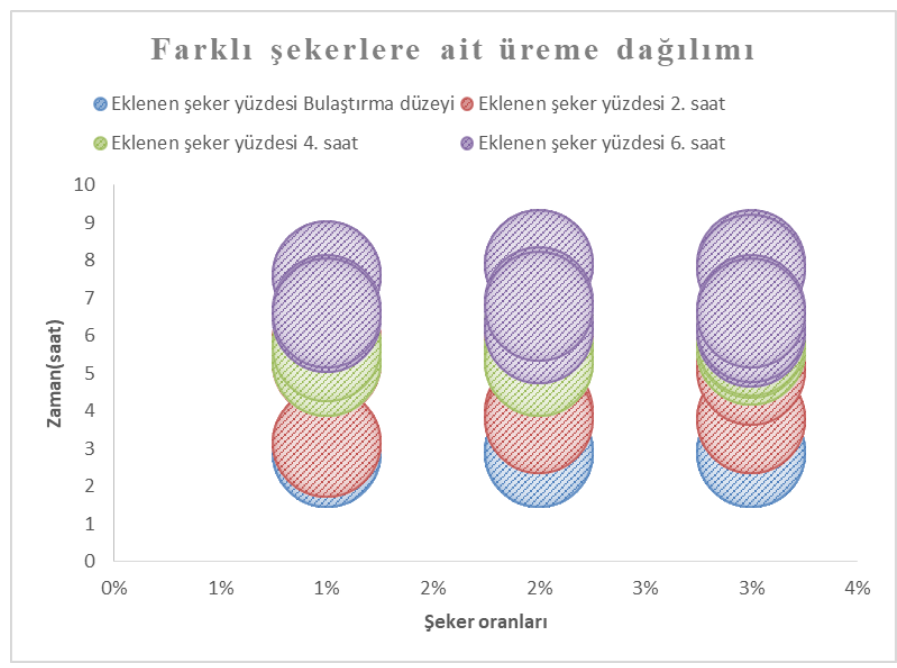

Şekil 8. Kullanılan şekerin yüzdesine bağlı üreme grafiği.

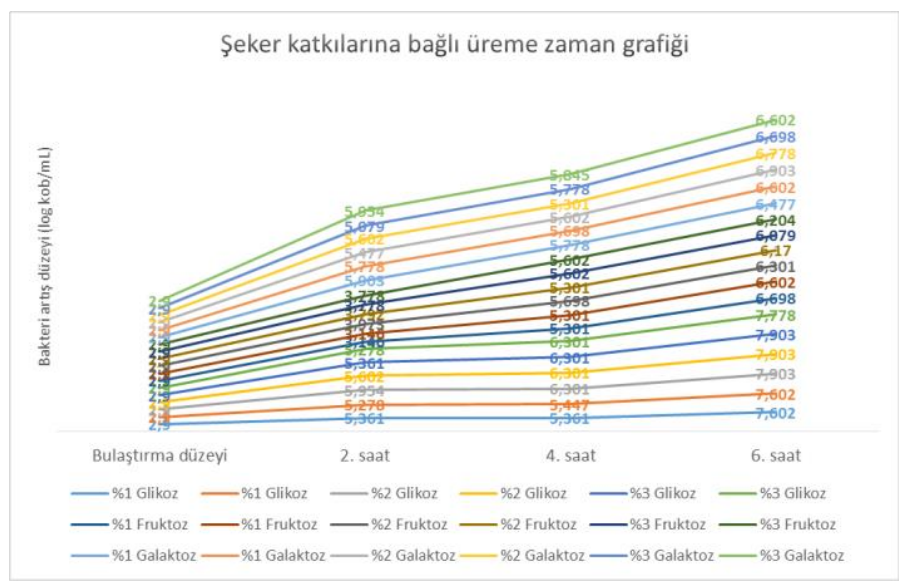

Şekil 9. Kullanılmış şeker yüzdesine bağlı ayrıntılı üreme grafiği.

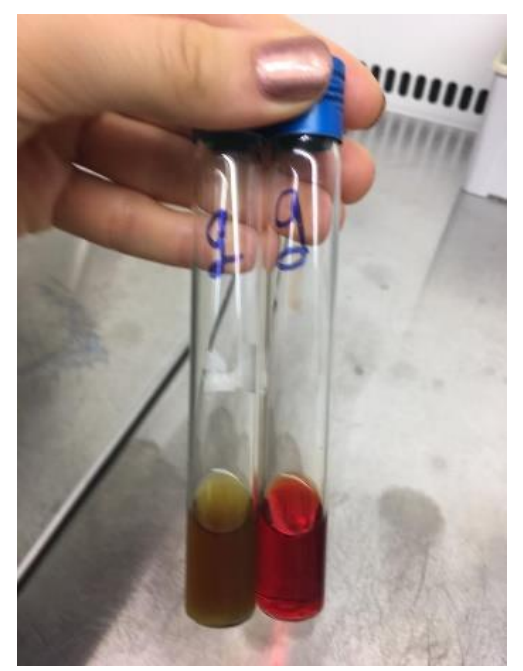

Şekil 10. Renk indikatörlerinin 24 saat sonundaki değişimi. 
Tablo 3

BCP indikatörünün süre ve yoğunluğa bağlı renk değişimleri.

\begin{tabular}{|c|c|c|c|c|c|c|c|c|c|}
\hline \multirow{3}{*}{ Süre } & \multicolumn{9}{|c|}{ İndikatör Çeşidine Bağlı Renk Değişimi } \\
\hline & \multicolumn{9}{|c|}{ Bromcreosol Purple } \\
\hline & $10^{1}$ & $10^{2}$ & $10^{3}$ & $10^{4}$ & $10^{5}$ & $10^{6}$ & $10^{7}$ & $10^{8}$ & $10^{9}$ \\
\hline 0. Saat & $\begin{array}{c}\text { Mevcut } \\
\text { değil }\end{array}$ & $\begin{array}{c}\text { Mevcut } \\
\text { değil }\end{array}$ & $\begin{array}{l}\text { Mevcut } \\
\text { değil }\end{array}$ & $\begin{array}{c}\text { Mevcut } \\
\text { değil }\end{array}$ & $\begin{array}{c}\text { Mevcut } \\
\text { değil }\end{array}$ & $\begin{array}{l}\text { Mevcut } \\
\text { değil }\end{array}$ & $\begin{array}{l}\text { Mevcut } \\
\text { değil }\end{array}$ & $\begin{array}{c}\text { Mevcut } \\
\text { değil }\end{array}$ & $\begin{array}{l}\text { Mevcut } \\
\text { değil }\end{array}$ \\
\hline 2. Saat & $\begin{array}{c}\text { Mevcut } \\
\text { değil }\end{array}$ & $\begin{array}{c}\text { Mevcut } \\
\text { değil }\end{array}$ & $\begin{array}{c}\text { Mevcut } \\
\text { değil }\end{array}$ & $\begin{array}{c}\text { Mevcut } \\
\text { değil }\end{array}$ & $\begin{array}{c}\text { Mevcut } \\
\text { değil }\end{array}$ & $\begin{array}{l}\text { Mevcut } \\
\text { değil }\end{array}$ & $\begin{array}{c}\text { Mevcut } \\
\text { değil }\end{array}$ & $\begin{array}{c}\text { Mevcut } \\
\text { değil }\end{array}$ & $\begin{array}{c}\text { Mevcut } \\
\text { değil }\end{array}$ \\
\hline 4. Saat & $\begin{array}{c}\text { Mevcut } \\
\text { değil }\end{array}$ & $\begin{array}{c}\text { Mevcut } \\
\text { değil }\end{array}$ & $\begin{array}{c}\text { Mevcut } \\
\text { değil }\end{array}$ & $\begin{array}{c}\text { Mevcut } \\
\text { değil }\end{array}$ & $\begin{array}{l}\text { Mevcut } \\
\text { değil }\end{array}$ & $\begin{array}{c}\text { Mevcut } \\
\text { değil }\end{array}$ & Mevcut & Mevcut & Mevcut \\
\hline 6. Saat & $\begin{array}{c}\text { Mevcut } \\
\text { değil }\end{array}$ & $\begin{array}{c}\text { Mevcut } \\
\text { değil }\end{array}$ & $\begin{array}{c}\text { Mevcut } \\
\text { değil }\end{array}$ & Mevcut & Mevcut & Mevcut & Mevcut & Mevcut & Mevcut \\
\hline 24. Saat & Mevcut & Mevcut & Mevcut & Mevcut & Mevcut & Mevcut & Mevcut & Mevcut & Mevcut \\
\hline
\end{tabular}

Tablo 4

Phenol red indikatörünün süre ve yoğunluğa bağlı renk değişimleri.

\begin{tabular}{|c|c|c|c|c|c|c|c|c|c|}
\hline \multirow{3}{*}{ Süre } & \multicolumn{9}{|c|}{ İndikatör Çeşidine Bağlı Renk Değişimi } \\
\hline & \multicolumn{9}{|c|}{ Phenol Red } \\
\hline & $10^{1}$ & $10^{2}$ & $10^{3}$ & $10^{4}$ & $10^{5}$ & $10^{6}$ & $10^{7}$ & $10^{8}$ & $10^{9}$ \\
\hline 0. Saat & $\begin{array}{c}\text { Mevcut } \\
\text { değil }\end{array}$ & $\begin{array}{c}\text { Mevcut } \\
\text { değil }\end{array}$ & $\begin{array}{c}\text { Mevcut } \\
\text { değil }\end{array}$ & $\begin{array}{c}\text { Mevcut } \\
\text { değil }\end{array}$ & $\begin{array}{c}\text { Mevcut } \\
\text { değil }\end{array}$ & $\begin{array}{c}\text { Mevcut } \\
\text { değil }\end{array}$ & $\begin{array}{c}\text { Mevcut } \\
\text { değil }\end{array}$ & $\begin{array}{l}\text { Mevcut } \\
\text { değil }\end{array}$ & $\begin{array}{l}\text { Mevcut } \\
\text { değil }\end{array}$ \\
\hline 2. Saat & $\begin{array}{c}\text { Mevcut } \\
\text { değil }\end{array}$ & $\begin{array}{c}\text { Mevcut } \\
\text { değil }\end{array}$ & $\begin{array}{c}\text { Mevcut } \\
\text { değil }\end{array}$ & $\begin{array}{c}\text { Mevcut } \\
\text { değil }\end{array}$ & $\begin{array}{c}\text { Mevcut } \\
\text { değil }\end{array}$ & $\begin{array}{c}\text { Mevcut } \\
\text { değil }\end{array}$ & $\begin{array}{c}\text { Mevcut } \\
\text { değil }\end{array}$ & $\begin{array}{c}\text { Mevcut } \\
\text { değil }\end{array}$ & $\begin{array}{l}\text { Mevcut } \\
\text { değil }\end{array}$ \\
\hline 4. Saat & $\begin{array}{c}\text { Mevcut } \\
\text { değil }\end{array}$ & $\begin{array}{c}\text { Mevcut } \\
\text { değil }\end{array}$ & $\begin{array}{c}\text { Mevcut } \\
\text { değil }\end{array}$ & $\begin{array}{c}\text { Mevcut } \\
\text { değil }\end{array}$ & $\begin{array}{c}\text { Mevcut } \\
\text { değil }\end{array}$ & $\begin{array}{c}\text { Mevcut } \\
\text { değil }\end{array}$ & $\begin{array}{c}\text { Mevcut } \\
\text { değil }\end{array}$ & $\begin{array}{c}\text { Mevcut } \\
\text { değil }\end{array}$ & $\begin{array}{c}\text { Mevcut } \\
\text { değil }\end{array}$ \\
\hline 6. Saat & $\begin{array}{c}\text { Mevcut } \\
\text { değil }\end{array}$ & $\begin{array}{c}\text { Mevcut } \\
\text { değil }\end{array}$ & $\begin{array}{c}\text { Mevcut } \\
\text { değil }\end{array}$ & $\begin{array}{c}\text { Mevcut } \\
\text { değil }\end{array}$ & $\begin{array}{c}\text { Mevcut } \\
\text { değil }\end{array}$ & $\begin{array}{c}\text { Mevcut } \\
\text { değil }\end{array}$ & $\begin{array}{c}\text { Mevcut } \\
\text { değil }\end{array}$ & Mevcut & Mevcut \\
\hline 24. Saat & Mevcut & Mevcut & Mevcut & Mevcut & Mevcut & Mevcut & Mevcut & Mevcut & Mevcut \\
\hline
\end{tabular}

Tablo 5

Spesifite test sonuçları.

\begin{tabular}{|c|c|c|c|c|c|c|c|c|c|c|}
\hline \multirow{3}{*}{$\begin{array}{l}\text { Bakteri } \\
\text { Adı }\end{array}$} & \multicolumn{10}{|c|}{ İnkübasyon Süreleri } \\
\hline & \multicolumn{2}{|c|}{ 2. Saat } & \multicolumn{2}{|c|}{ 4. Saat } & \multicolumn{2}{|c|}{ 6. Saat } & \multicolumn{2}{|c|}{ 8. Saat } & \multicolumn{2}{|c|}{ 24. Saat } \\
\hline & $\begin{array}{c}\text { Renk } \\
\text { Değişimi }\end{array}$ & $\begin{array}{c}\text { Donanım } \\
\text { Ölçümü }\end{array}$ & $\begin{array}{c}\text { Renk } \\
\text { Değişimi }\end{array}$ & $\begin{array}{c}\text { Donanım } \\
\text { Ölçümü }\end{array}$ & $\begin{array}{c}\text { Renk } \\
\text { Değişimi }\end{array}$ & $\begin{array}{c}\text { Donanım } \\
\text { Ölçümü }\end{array}$ & $\begin{array}{c}\text { Renk } \\
\text { Değişimi }\end{array}$ & $\begin{array}{c}\text { Donanım } \\
\text { Ölçümü }\end{array}$ & $\begin{array}{c}\text { Renk } \\
\text { Değişimi }\end{array}$ & $\begin{array}{c}\text { Donanım } \\
\text { Ölçümü }\end{array}$ \\
\hline $\begin{array}{l}\text { Escheric- } \\
\text { hia coli } \\
\text { ATCC } \\
25922\end{array}$ & $\begin{array}{l}\text { Renk } \\
\text { değişimi } \\
\text { yok }\end{array}$ & $\begin{array}{l}\text { MRSA } \\
\text { gözlemlen- } \\
\text { medi }\end{array}$ & $\begin{array}{c}\text { Renk } \\
\text { değişimi } \\
\text { yok }\end{array}$ & $\begin{array}{l}\text { MRSA } \\
\text { gözlemlen- } \\
\text { medi }\end{array}$ & $\begin{array}{l}\text { Renk } \\
\text { değişimi } \\
\text { yok }\end{array}$ & $\begin{array}{l}\text { MRSA } \\
\text { gözlemlen- } \\
\text { medi }\end{array}$ & $\begin{array}{l}\text { Renk } \\
\text { değişimi } \\
\text { yok }\end{array}$ & $\begin{array}{l}\text { MRSA } \\
\text { gözlemlen- } \\
\text { medi }\end{array}$ & $\begin{array}{c}\text { Renk } \\
\text { değişimi } \\
\text { yok }\end{array}$ & $\begin{array}{l}\text { MRSA } \\
\text { gözlemlen- } \\
\text { medi }\end{array}$ \\
\hline $\begin{array}{l}\text { Staphylo- } \\
\text { coccus } \\
\text { epidemidis } \\
\text { ATCC } \\
\mathbf{1 2 2 2 8}\end{array}$ & $\begin{array}{l}\text { Renk } \\
\text { değişimi } \\
\text { yok }\end{array}$ & $\begin{array}{l}\text { MRSA } \\
\text { gözlemlen- } \\
\text { medi }\end{array}$ & $\begin{array}{l}\text { Renk } \\
\text { değişimi } \\
\text { yok }\end{array}$ & $\begin{array}{l}\text { MRSA } \\
\text { gözlemlen- } \\
\text { medi }\end{array}$ & $\begin{array}{c}\text { Renk } \\
\text { değişimi } \\
\text { yok }\end{array}$ & $\begin{array}{l}\text { MRSA } \\
\text { gözlemlen- } \\
\text { medi }\end{array}$ & $\begin{array}{l}\text { Renk } \\
\text { değişimi } \\
\text { yok }\end{array}$ & $\begin{array}{l}\text { MRSA } \\
\text { gözlemlen- } \\
\text { medi }\end{array}$ & $\begin{array}{c}\text { Renk } \\
\text { değişimi } \\
\text { yok }\end{array}$ & $\begin{array}{l}\text { MRSA } \\
\text { gözlemlen- } \\
\text { medi }\end{array}$ \\
\hline $\begin{array}{l}\text { Bacillus } \\
\text { subtilis } \\
\text { ATCC } \\
6633\end{array}$ & $\begin{array}{c}\text { Renk } \\
\text { değişimi } \\
\text { yok }\end{array}$ & $\begin{array}{l}\text { MRSA } \\
\text { gözlemlen- } \\
\text { medi }\end{array}$ & $\begin{array}{l}\text { Renk } \\
\text { değişimimi } \\
\text { yok }\end{array}$ & $\begin{array}{l}\text { MRSA } \\
\text { gözlemlen- } \\
\text { medi }\end{array}$ & $\begin{array}{c}\text { Renk } \\
\text { değişimi } \\
\text { yok }\end{array}$ & $\begin{array}{l}\text { MRSA } \\
\text { gözlemlen- } \\
\text { medi }\end{array}$ & $\begin{array}{c}\text { Renk } \\
\text { değişimi } \\
\text { yok }\end{array}$ & $\begin{array}{l}\text { MRSA } \\
\text { gözlemlen- } \\
\text { medi }\end{array}$ & $\begin{array}{c}\text { Renk } \\
\text { değişimi } \\
\text { yok }\end{array}$ & $\begin{array}{l}\text { MRSA } \\
\text { gözlemlen- } \\
\text { medi }\end{array}$ \\
\hline $\begin{array}{l}\text { Listeria } \\
\text { mono- } \\
\text { cytogenes } \\
\text { ATCC } \\
19115\end{array}$ & $\begin{array}{l}\text { Renk } \\
\text { değişimi } \\
\text { yok }\end{array}$ & $\begin{array}{l}\text { MRSA } \\
\text { gözlemlen- } \\
\text { medi }\end{array}$ & $\begin{array}{l}\text { Renk } \\
\text { değişimi } \\
\text { yok }\end{array}$ & $\begin{array}{l}\text { MRSA } \\
\text { gözlemlen- } \\
\text { medi }\end{array}$ & $\begin{array}{l}\text { Renk } \\
\text { değişimi } \\
\text { yok }\end{array}$ & $\begin{array}{l}\text { MRSA } \\
\text { tespit } \\
\text { edilmedi }\end{array}$ & $\begin{array}{l}\text { Renk } \\
\text { değişimi } \\
\text { yok }\end{array}$ & $\begin{array}{l}\text { MRSA } \\
\text { tespit } \\
\text { edilmedi }\end{array}$ & $\begin{array}{l}\text { Renk } \\
\text { değişimi } \\
\text { yok }\end{array}$ & $\begin{array}{l}\text { MRSA } \\
\text { gözlemlen- } \\
\text { medi }\end{array}$ \\
\hline $\begin{array}{l}\text { Enterococ- } \\
\text { cus faecalis } \\
\text { ATCC } \\
29212\end{array}$ & $\begin{array}{c}\text { Renk } \\
\text { değişimi } \\
\text { yok }\end{array}$ & $\begin{array}{l}\text { MRSA } \\
\text { gözlemlen- } \\
\text { medi }\end{array}$ & $\begin{array}{c}\text { Renk } \\
\text { değişimi } \\
\text { yok }\end{array}$ & $\begin{array}{l}\text { MRSA } \\
\text { gözlemlen- } \\
\text { medi }\end{array}$ & $\begin{array}{c}\text { Renk } \\
\text { değişimi } \\
\text { yok }\end{array}$ & $\begin{array}{l}\text { MRSA } \\
\text { tespit } \\
\text { edilmedi }\end{array}$ & $\begin{array}{c}\text { Renk } \\
\text { değişimi } \\
\text { yok }\end{array}$ & $\begin{array}{c}\text { MRSA } \\
\text { tespit } \\
\text { edilmedi }\end{array}$ & $\begin{array}{c}\text { Renk } \\
\text { değişimi } \\
\text { yok }\end{array}$ & $\begin{array}{l}\text { MRSA } \\
\text { gözlemlen- } \\
\text { medi }\end{array}$ \\
\hline $\begin{array}{l}\text { Proteus } \\
\text { mirabilis } \\
\text { ATCC } \\
\mathbf{1 2 4 5 3}\end{array}$ & $\begin{array}{c}\text { Renk } \\
\text { değisisimi } \\
\text { yok }\end{array}$ & $\begin{array}{l}\text { MRSA } \\
\text { gözlemlen- } \\
\text { medi }\end{array}$ & $\begin{array}{c}\text { Renk } \\
\text { değişimi } \\
\text { yok }\end{array}$ & $\begin{array}{l}\text { MRSA } \\
\text { gözlemlen- } \\
\text { medi }\end{array}$ & $\begin{array}{c}\text { Renk } \\
\text { değişimi } \\
\text { yok }\end{array}$ & $\begin{array}{l}\text { MRSA } \\
\text { tespit } \\
\text { edilmedi }\end{array}$ & $\begin{array}{c}\text { Renk } \\
\text { değişimi } \\
\text { yok }\end{array}$ & $\begin{array}{c}\text { MRSA } \\
\text { tespit } \\
\text { edilmedi }\end{array}$ & $\begin{array}{c}\text { Renk } \\
\text { değişimi } \\
\text { yok }\end{array}$ & $\begin{array}{l}\text { MRSA } \\
\text { gözlemlen- } \\
\text { medi }\end{array}$ \\
\hline $\begin{array}{l}\text { Pseudomo- } \\
\text { nas } \\
\text { aeruginosa } \\
\text { ATCC } \\
24853\end{array}$ & $\begin{array}{c}\text { Renk } \\
\text { değişimi } \\
\text { yok }\end{array}$ & $\begin{array}{l}\text { MRSA } \\
\text { gözlemlen- } \\
\text { medi }\end{array}$ & $\begin{array}{c}\text { Renk } \\
\text { değişimi } \\
\text { yok }\end{array}$ & $\begin{array}{l}\text { MRSA } \\
\text { gözlemlen- } \\
\text { medi }\end{array}$ & $\begin{array}{c}\text { Renk } \\
\text { değişimi } \\
\text { yok }\end{array}$ & $\begin{array}{l}\text { MRSA } \\
\text { gözlemlen- } \\
\text { medi }\end{array}$ & $\begin{array}{l}\text { Renk } \\
\text { değişimimi } \\
\text { yok }\end{array}$ & $\begin{array}{l}\text { MRSA } \\
\text { gözlemlen- } \\
\text { medi }\end{array}$ & $\begin{array}{c}\text { Renk } \\
\text { değişimi } \\
\text { yok }\end{array}$ & $\begin{array}{l}\text { MRSA } \\
\text { gözlemlen- } \\
\text { medi }\end{array}$ \\
\hline
\end{tabular}


Farklı şekerlerin üremelerinin dağılımının özet grafiği Şekil 8'de, kullanılmış şeker katkılarının ve zamana bağlı dağılımın detaylı grafiği Şekil 9'da verilmektedir.

Tablo 2, Şekil 8 ve Şekil 9 göstermektedir ki, zamana bağlı üreme eğrisi 6 saatte belirgin olarak yüksektir ve istatistiki anlamda önemli düzeyde $(p<0.05)$ artmıştır.

Tablo 3'te BCP indikatörünün zamansal olarak belirli yoğunluklarda bakteri üreme sonuçları, Tablo 4'te ise phenol red zamansal olarak belirli yoğunluklardaki bakteri üreme sonuçları verilmiştir.

Renk değişimleri incelendiğinde, BCP indikatörünün daha hızlı renk değişimine sebep olduğu gözlemlenmiştir. Şekil 10'da inkübasyon işleminden sonra renk indikatörlerindeki değişimler görülmektedir.

\section{2. Özgüllük (spesifite) testi sonuçlart}

Özgüllük testi yapıldığında, hiçbir bakteri 24 saat içinde görsel olarak donanımın okuyabileceği seviyede ve renkte değişikliği tetiklememiştir. Bununla ilgili bulgular Tablo 5'de özetlenmiştir.

Şekil 11'de spesifite için gerekli bakterilerin görüntüleri ve sistem cevabı (inkübasyon işleminden sonra) bulunmaktadır.

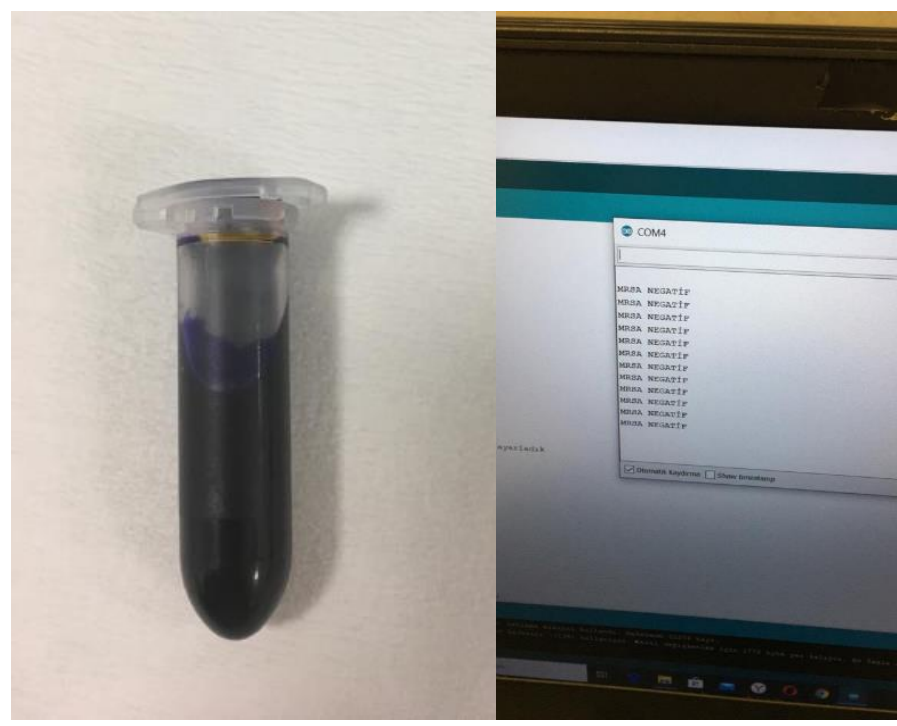

Şekil 11. Yirmi dört saatte spesifite için yapılan testte kullanılan $S$. epidermidis'e ait görüntü (tüm bakterilerde aynı olduğu için temsilen eklenmiştir).

\subsection{Verifikasyon uygulamast}

Verifikasyon uygulamasının saatleri ve sonuçları Tablo 6'da verilmiştir.

Saat 9:00'da, 24 saatin sonunda, renkler tüm yoğunluklarda tamamen dönmüştür. Sistem tekrarlandığında tüm yoğunluklar için RGB sensörü yeşildir. "MRSA POZİTİF. LÜTFEN KLASIK KÜLTÜR YÖNTEMİ İLE DOĞRULAYINIZ" uyarısı Seriport ekranında belirmiştir.

MRSA üremesi sayesinde tüm yoğunluktaki brothlarda 24 saatin sonunda renklerin sarıya döndüğü gözlemlenmiştir. Şekil 12'de brothlarda oluşan renk değişimleri bulunmaktadır.

Yaptığımız çalışmanın amacı, MRSA tespitine yönelik hızlı bir sistem kullanılmasıdır. Kurulan düzenekte, farklı şeker katkılarıyla oluşturulan besi yerlerinde MRSA üremesiyle bağlantılı $\mathrm{pH}$ değişikliğine yanıt veren renk indikatörlerinin optik bir donanımla algılanması hedeflenmiştir.
Tablo 6

Verifikasyon uygulama sonuçları.

\begin{tabular}{|c|c|c|c|}
\hline \multirow[t]{2}{*}{$\begin{array}{c}\text { Ölçüm } \\
\text { Saati }\end{array}$} & \multicolumn{3}{|c|}{ Bulaştırma Düzeyi } \\
\hline & $\begin{array}{c}\text { Düşük } \\
\text { Yoğunluk }\end{array}$ & $\underset{\text { Orta }}{\text { Yoğunluk }}$ & $\begin{array}{c}\text { Yüksek } \\
\text { Yoğunluk }\end{array}$ \\
\hline 09:00 & $\begin{array}{c}\text { Tespit } \\
\text { edilemedi }\end{array}$ & Tespit edilemedi & Tespit edilemedi \\
\hline 11:00 & $\begin{array}{c}\text { Tespit } \\
\text { edilemedi }\end{array}$ & Tespit edilemedi & Tespit edilemedi \\
\hline 13:00 & $\begin{array}{c}\text { Tespit } \\
\text { edilemedi }\end{array}$ & Tespit edilemedi & Tespit edilemedi \\
\hline 15:00 & $\begin{array}{c}\text { Tespit } \\
\text { edilemedi }\end{array}$ & Tespit edilemedi & MRSA tespit edildi \\
\hline 17:00 & $\begin{array}{c}\text { Tespit } \\
\text { edilemedi }\end{array}$ & Tespit edilemedi & MRSA tespit edildi \\
\hline 19:00 & $\begin{array}{c}\text { Tespit } \\
\text { edilemedi }\end{array}$ & $\begin{array}{l}\text { MRSA tespit } \\
\text { edildi }\end{array}$ & MRSA tespit edildi \\
\hline 21:00 & $\begin{array}{c}\text { MRSA tespit } \\
\text { edildi }\end{array}$ & $\begin{array}{c}\text { MRSA tespit } \\
\text { edildi }\end{array}$ & MRSA tespit edildi \\
\hline $\begin{array}{c}\text { 09:00 } \\
\text { (24. Saat) }\end{array}$ & $\begin{array}{c}\text { MRSA tespit } \\
\text { edildi }\end{array}$ & $\begin{array}{c}\text { MRSA tespit } \\
\text { edildi }\end{array}$ & MRSA tespit edildi \\
\hline
\end{tabular}

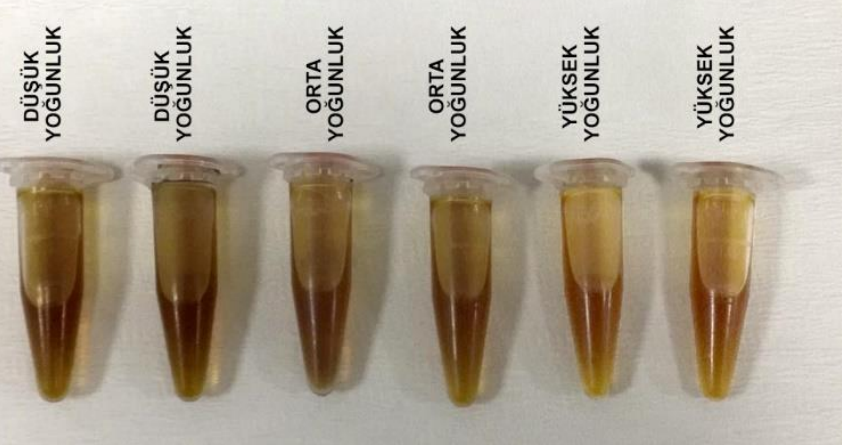

Şekil 12. Brothlarda bakteri üremesine bağlı oluşan renk değişimleri.

ISO 6888-1 kapsamındaki referans olan malzeme çalışmalarında $5000 \mathrm{kob} / \mathrm{mL}$ içeren sertifikalı referans malzeme kullanılmış ve standart sapma 1,76 oranında belirlenmiştir. $\mathrm{Bu}$ çalışmadaki $\pm 0,193$ sonucu, standartla belirlenmiş olan standart sapmanın altındadır ve \%95 güven aralığıyla sonuç alınabileceğini göstermektedir (ISO-6888, 1999).

Farklı şeker katkılarındaki paralel ekim sonuçları, altıncı saat itibariyle 6,079-7,903 $\log _{10} \mathrm{kob} / \mathrm{mL}$ seviyesindedir. Zaman odaklı üreme eğrisi 6 saat içerisinde belirgin şekilde yüksektir ve istatistiki anlamda önemli ölçüde $(p<0.05)$ artmıştır. Staphylococcus türlerindeki pentoz şekerlerin tümünden enerji dönüşümünün elde edildiği literatürde bildirilmiştir (Strasters ve Winkler, 1963). Başka bir çalışma Staphylococcus türevlerinin şeker alımı açısından benzersiz bir transport sistemleri olduğu ve şekerlerden maksimum düzeyde yarar sağladıklarını göstermektedir (Grosser ve ark., 2016). Bu sonuç, çalışmamızın sonunda bütün şeker türlerinden benzer olarak cevap almamızı açıklamaktadır.

Çalışmamızdaki renk değişimleri incelediğinde, Brom Creosol Purple (BCP) indikatörünün renk değişimini daha erken başlattığı gözlemlenmiştir. $\mathrm{BCP} \mathrm{pH}$ göstergesi niteliğinde kullanılmıştır. pH 5,2'nin altında olursa, BCP'de sarı renk görülmektedir. $\mathrm{BCP}$ içerisinde $\mathrm{pH}$ 6,8' in üzerinde olduğunda ise, mor renk alır. Phenol red diğer renk indikatörü olarak kullanılmıştır ve pH 6,6'nın altındayken sarı, $\mathrm{pH}$ 8'in yukarısındayken kırmızı renk görünmektedir. Farklı bir çalışmada ise bu indikatörlerden dolayı herhangi bir farklılık 
gözlemlenmediği belirtilmiştir (Chesney, 1922). Çalışmamızda gözlediğimiz bu farkın muhtemel nedeninin kullanılan şeker ekleri ve bakterinin farklılığı olduğu düşünülmektedir.

Verifikasyon işlemi sabah 9:00'da başlamıştır. Ardından, sistematik olarak belirli saatlerde sistem optimizasyonu yapılmıştır. Bulaştırmanın altıncı saatinde (saat 15:00) ilk pozitif cevap ölçülmüş ve yüksek konsantrasyonda olduğu gözlemlenmiştir. Yapılan bir çalışmada, hastaların çevreleri ve ellerinden alınan sayım göstermektedir ki, hastanın ellerinde ve temas ettiği yüzeylerde bulaşma 0-6 log arasında değişmektedir. Özellikle el örnekleri, $6 \log _{10} \mathrm{kob} / \mathrm{cm}^{2}$ seviyesinde bulaşma olduğunu göstermişlerdir. Çalışmamızda 6. saat itibariyle yüksek bulaşma ile alınan cevabın hız açısından yeterli olabileceği düşünülmektedir (Kamiya ve ark., 2007).

Yaptığımız optik sistemde hassasiyet göz önüne alındığında $2 \log _{10} \mathrm{kob} / \mathrm{mL}$ bulaştırma seviyesinde en geç 8 saat içinde sonuç alındığı gözlemlenmiştir. Bu bilgiler 1şı̆̆ında klasik kültür tekniklerinde tespit süreleri ve tespit sınırları ISO 6888-1 içerisinde 4 gün içerisinde sonuç vermiştir. 3,27 $\log _{10} \mathrm{kob} / \mathrm{mL}$ seviyesinde bu sonucun alındığı bildirilmiştir. Diğer çalışmalarda kültür tekniği kullanıldığında disk difüzyon testlerinin duyarlılığının 48 saat sonrasında güvenilir olduğu anlaşılmıştır. Kültür yöntemi olarak kullanılan mikrodilisyon yönteminde 24 saat sonunda veri alınmaktadır (Velasco ve ark., 2005). Diğer bir yöntem olan oksasilin agar tarama yöntemleri ve oksasilin disk yöntemi MRSA tanımlanmasında kullanılmıştır. Bu iki yöntemde de inkübasyon için 24 saat beklenmektedir. $\mathrm{Bu}$ sürecin sonunda agar tarama yönteminin duyarlılığ1 \%91,7 iken, oksasilin disk difüzyon yönteminin duyarlılığ $1 \% 83,5$ olarak bildirilmiştir (Cavassini ve ark., 1999). Benzer sonuçlara ISO ile de ulaşılmıştır. Bir S. aureus ile ilgili olarak toplam pozitif 91 kan kültürünün 40' 1 MSSA, 51'i MRSA örneği olmak üzere PBP (penisilin bağlayan protein) testi ne uygulanmıştır. Özgüllük ve duyarlılık değerleri \%97,5 ve \%94,1 olarak belirlenmiştir (Gold ve ark., 2010). Yaptığımız optik sistemde brothların içerisindeki şeker oranları ve kullanılan renk indikatörünün etkilediği düşünülmüştür. Ayrıca, sistemimizde renk hassasiyetinin yüksek olmasına da katkısı olduğu kanaatine varılmıştır.

Yapılan bir çalışmada ELISA testinin inkübasyon için minimum 16 saat beklenilmesi gerektiği bildirilmiştir. Test süresi uzun olan ELISA sisteminin yüksek hassasiyet ve özgüllüğe sahip olduğu belirlenmiştir. Bu test sisteminde örnek alımı teknisyen tarafından yapıldığı için yanlış sonuçların belli bir bölümünü teknisyen hatası oluşturmaktadır (Boutonnier ve ark., 1989). ELISA birçok basamaktan oluştuğu için teknisyenin özenli bir şekilde çalışma yapması gerekmektedir. ELISA aynı zamanda yüksek maliyetli bulunmuştur (Hicks ve ark., 1994; Le Blay ve ark., 2004).

Eklenen şeker katkılarının MRSA tarafından enerjiye dönüştürülmesinin sonucu ortamda $\mathrm{pH}$ değişiminin tetiklediği indikatörde renk değişimi olmasından dolayı, kurulan sistemin PCR gibi hassas bir yöntemden önce tarama testi olarak kullanılması düşünülmektedir. PCR ile yapılan çalışmalar göstermektedir ki PCR'nin hassasiyeti çok yüksektir, fakat maliyetin de yüksektir. Ek bir donanım ve ayrı analiz protokolleri gerektirmektedir.

PCR analizinden elde edilen sonuçlar üzerinde inhibitörlerin etkin olduğu belirlenmiştir (Monteiro ve ark., 1997; Braid ve ark., 2003; Schrader ve ark., 2012).

Polimeraz zincir reaksiyonu enzimatik bir reaksiyondur ve inhibitör maddeler karşısında duyarlılık göstermektedir. PCR inhibitörlerinin yapılan testlerin farklı aşamalarında farklı mekanizmalarla etkileşen maddeler oldukları belirlenmiştir. PCR inhibitörleri organik veya inorganik maddelerdir ve sıv1 veya katı formda bulunabilirler. İmmünoglobin (IgG), laktoferrin, hemoglobin, kollajen, proteinler, miyoglobin ve proteinazlar organik inhibitörlere örnek olarak gösterilebilirler. Etanol, fenol humik asitler, tanik, safra tuzları, üre ve melanin ise inorganik inhibitörlere örnektir. $\mathrm{Bu}$ inhibitörler ile PCR testinin sonucu olumsuz olarak etkilenebilir. Bununla birlikte, PCR testinin duyarlılığını da negatif yönde etkileyebildikleri görülmüştür (Kim ve ark., 1992; Löfström ve ark., 2004).

PCR testi ile MRSA tespiti 4 saatten daha az sürmektedir ve oldukça yüksek hassasiyete sahiptir (Baby ve ark., 2017). Real-time PCR testleri geleneksel kültür yöntemlerine kıyasla MRSA'y1 daha hılı tespit etmektedir. MRSA tespitinde PCR'nin özgüllüğünün saf koloniler için $\% 100$ oranında olduğu belirlenmiştir. PCR testlerinin hassasiyet ve özgüllük değeri diğer tespit sistemlerine nazaran daha yüksektir ve bu testler 10$15 \mathrm{dk}$. arasında sonuç vermektedir (Warren ve ark., 2004). Öte yandan PCR'nin uygulanmasında eğitimli teknisyen olma zorunluluğu ve PCR'nin yüksek maliyetli olması, tarama yöntemi olarak tercih edilmesini güçleştirmektedir.

Optik donanımlarla hazırlanmış olan cihazlar göstermektedir ki, çalışmamızda kullanılan TCS 3200 ile yaptığımız analiz sonuçları güvenlidir ve elde edilen sonuçların doğruluğu uygulamada da kanıtlanmıştır (Fitriyah ve ark., 2018).

Literatürdeki bir çalışma kapsamında biyosensör içerisinde bulunan algılama platformuna altın kaplama yapılmış, nonobead yardımıyla S. aureus proteaz olan spesifik substrat kaplanmıştır. $S$. aureus tanısal algılama platformudur ve proteazların proteolitik aktivitesini ölçer. Ortaya çıkan enzimatik reaksiyon altın tabakasında bir renk değişimine sebep olmaktadır. Bir hassasiyet testi farklı yoğunluklarda bulunan bakteri yardımıyla yapılmıştır. $\mathrm{Bu}$ sensörden $10^{5}$ yoğunluğunda $\% 36,10^{4}$ yoğunluğunda $\% 28$ ve $10^{3}$ yoğunluğunda \%22 oranında sonuç elde edildiği için, sensörün yeterli hassasiyete sahip olduğu kabul edilmiştir. Çalışmamızda kalitatif (çıplak gözle yapılımıştır) ve kantitatif (görüntüleme yazılımı) yöntemlerle sensörün hassasiyeti test edilmiştir (Suaifan ve ark., 2017). Çalışmamızın renk indikatöründeki renk değişimi kalitatif olarak, RGB renk sensörü renk değişimi kalitatif olarak yazılım ile uyarı sistemlerinden meydana gelmektedir. Literatürdeki bir başka çalışma, IgG'nin S. aureus ile Fc bölgesi arasında spesifik etkileşime dayalı elektromilüminesan (ECL) biyosensörü geliştirilmesi ile ilgilidir. $\mathrm{Bu}$ biyosensör $10^{3}$ yoğunluğunda $\% 2,5,10^{5}$ yoğunluğunda $\% 2,6$ ve $10^{9}$ yoğunluğunda $\% 5,9$ değerlerindedir ve biyosensörün özgüllüğü test edilmiştir (Yue ve ark., 2016).

Çalışmamızda kurmuş olduğumuz optik sistemde temel parametre $\mathrm{pH}$ değişimidir. Brothlarda değişen $\mathrm{pH}$, hem serbest iyon sayısında, hem de ortam renginde değişim yaratır. Serbest iyon değişimi de sistem için baz alınabilir. Serbest iyon değişiminin ortamdaki akım üzerinde etkisi olduğu belirlenmiştir. $\mathrm{Bu}$ akımda oluşan değişim baz alınarak amperometrik hızlı tespit sistemi kurulabilir. Bu sistemde akım değişimi ölçülüp bakterinin varlığı belirlenebilir. Brothlar içerisinde meydana gelen $\mathrm{pH}$ değişimi ve serbest iyonlar ortamın voltajı üzerinde etkilidirler. Voltmetrik hızlı tespit sistemi ile bakterinin varlığı tespit edilebilmesi için bu voltajda oluşan değişimi baz almak gereklidir.

Brothlar içerisinde değişen $\mathrm{pH}$ değeri ile ilgili renk değiştirmesi ve sistemdeki renk değişimini test etmesi bakımından, kurduğumuz optik sistemin büyük bir avantajı 
vardır. Hiçbir elektrota ve kimyasal maddeye bu donanımda ihtiyaç doğmamaktadır. Kullanım ömürleri kısadır; zira elektrotlarda besiyerleriyle etkileşim oluşmaktadır.

Çalışmamızda uyguladığımız sisteme yönelik bir diğer avantaj, sistemin taşınabilir yani ergonomik olmasıdır. Güç devresi optik sisteme dâhil edileceğinden, ebat ölçüsünün $6 \times 13$ cm olması planlanmaktadır.

\section{Sonuç}

Çoklu antibiyotik direncine bağlı olarak, MRSA hastane enfeksiyonun en önemli etkenlerindendir. $\mathrm{Bu}$ etken tespit edildiği taktirde, enfeksiyon kontrolünde önemli bir basamak kat edilecektir.

Çalışmamız kapsamında tasarlanan hızlı tespit sisteminin amac1, MRSA tespitinde süregelen teşhis yöntemlerinin dezavantajlarını aza indirgemektir. Elde ettiğimiz sonuçlar göstermektedir ki, sistemimizden kısa bir sürede sonuç alınmaktadır. Alışılmış enfeksiyon kontrol stratejilerinde daha çok klasik kültür tekniği uygulanmaktadır. Bu tekniklerle süre

\section{Kaynaklar}

Appelbaum, P. C. (2006). MRSA the tip of the iceberg. Clinical Microbiology and Infection, 12, 3-10.

Baby, N., Faust, A. C., Smith, T., Sheperd, L. A., Knoll, L., \& Goodman, E. L. (2017). Nasal MRSA PCR testing reduces duration of MRSAtargeted therapy in patients with suspected MRSA pneumonia. Antimicrobial Agents and Chemotherapy, 61(4), 1-8.

Becker, K., Skov, R. L., \& von Eiff, C. (2015). Staphylococcus, Micrococcus, and other catalase-positive cocci. Manual of Clinical Microbiology, 354-382.

Cavassini, M., Wenger, A., Jaton, K., Blanc, D. S., \& Bille, J. (1999). Evaluation of MRSA-Screen, a simple anti-PBP 2a slide latex agglutination kit, for rapid detection of methicillin resistance in Staphylococcus aureus. Journal of Clinical Microbiology, 37(5), 15911594.

Boutonnier, A., Nato, F., Bouvet, A., Lebrun, L., Audurier, A., Mazie, J. C., \& Fournier, J. M. (1989). Direct testing of blood culture for detection of the serotype 5 and 8 capsular polysaccharides of Staphylococcus aureus. Journal of Clinical Microbiology, 27(5), 989-993.

Braid, M. D., Daniels, L. M., \& Kitts, C. L. (2003). Removal of PCR inhibitors from soil DNA by chemical flocculation. Journal of Microbiological Methods, 52(3), 389-393.

Cadena, J., Thinwa, J., Walter, E. A., \& Frei, C. R. (2016). Risk factors for the development of active methicillin-resistant Staphylococcus aureus (MRSA) infection in patients colonized with MRSA at hospital admission. American Journal of Infection Control, 44(12), 1617-1621.

Chesney, A. M. (1922). The use of phenol red and brom-cresol purple as indicators in the bacteriological examination of stools. The Journal of Experimental Medicine, 35(2), 181.

Fitriyah, L. A., Indahwati, E., \& Wardana, H. K. (2018). Measurement of Non-Invasive Blood Glucose Level Based Sensor Color TCS3200 and Arduino. IOP Conference Series: Materials Science and Engineering, $336(1), 1-6$.

Fridkin, S. K., Welbel, S. F., \& Weisten, R. A. (1997). Magnitude and prevention of nosocomial infection in Intensive Care Unit. Infectious Disease Clinics of North America, 11, 479-496.

Gold, H. S., Kirby, J. E., Qian, Q., Venkataraman, L., \& Yamazumi, T. (2010). Direct detection of methicillin resistance in Staphylococcus aureus in blood culture broth by use of a penicillin binding protein $2 \mathrm{a}$ latex agglutination test. Journal of Clinical Microbiology, 48(4), 14201421.

Grosser, M. R., Khatri, D., Lance, T. R., Richardson, A. R., \& Vitko, N. P. (2016). Expanded glucose import capability affords Staphylococcus aureus optimized glycolytic flux during infection. American Society for Microbiology, 7(3), 1-10.

Hicks, C. R., Eberhart, R. J., \& Sischo, W. M. (1994). Comparison of microbiologic culture, an enzyme-linked immunosorbent assay, and determination of somatic cell count for diagnosing Staphylococcus olarak müdahalede gecikilebileceği gibi, hayatta kalım da riske atılabilir.

Çalışmamız kapsamında MRSA tespiti için tasarlanan sistemin PCR tekniğinden önce tarama sistemi olarak kullanılacağını ve bu sistemin MRSA enfeksiyon kontrolünde önemli bir role sahip olacağını öngörüyoruz.

Hastanelerde enfeksiyon yayılımını takip edebilmek için bu optik temelli sistemin kullanılabileceğini düşünüyoruz.

Teşekkür: Bu çalışma Pamukkale Üniversitesi Fen Bilimleri Enstitüsü Biyomedikal Mühendisliği Anabilim Dalı yüksek lisans programı kapsamında yazılan yüksek lisans tezinden hazırlanmıştır.

Çıkar çatışması: Yazarlar herhangi bir çıkar çatışması olmadığını beyan eder.

Etik beyanı: Bu çalışmada, yazarlar, hiç bir insan ya da hayvan denek kullanılmadığını ve Etik Kurul iznine gerek olmadığını beyan eder. aureus mastitis in dairy cows. Journal of the American Veterinary Medical Association, 204(2), 255-260.

Hidron, A. I., Kourbatova, E. V., Halvosa, J. S., Terrell, B. J., McDougal, L. K., Tenover, F. C., ... \& King, M. D. (2005). Risk factors for colonization with methicillin-resistant Staphylococcus aureus (MRSA) in patients admitted to an urban hospital: emergence of communityassociated MRSA nasal carriage. Clinical Infectious Diseases, 41(2), $159-166$

ISO-6888. (1999). Microbiology of food and animal feeding stuffs horizontal method for the enumeration of coagulase-positive staphylococci (Staphylococcus aureus and other species) - part 1: technique using Baird-Parker agar (ISO 6888-1). 1sted. ISOMicrobiology. Geneva (Switzerland). pp. 1-11.

Kamiya, A., Oie, S. Sawa, \& A. Suenaga, S. (2007). Association between isolation sites of methicillin-resistant Staphylococcus aureus (MRSA) in patients with MRSA-positive body sites and MRSA contamination in the surrounding environmental surfaces. Japanese Journal of Infectious Diseases, 60(6), 367-369.

Kim, H., Pernille, N., Rasmussen, O. F., \& Rossen, L. (1992). Inhibition of PCR by components of food samples, microbial diagnostic assays and DNA-extraction solutions. International Journal of Food Microbiology, 17(1), 37-45.

Le Blay, G., Fliss, I., \& Lacroix, C. (2004). Comparative detection of bacterial adhesion to Caco- 2 cells with ELISA, radioactivity and plate count methods. Journal of Microbiological Methods, 59(2), 211-221.

Löfström, C., Knutsson, R., Axelsson, C. E., \& Rådström, P. (2004). Rapid and specific detection of Salmonella spp. in animal feed samples by PCR after culture enrichment. Applied and Environmental Microbiology, 70(1), 69-75.

Monteiro, L., Bonnemaison, D., Vekris, A., Petry, K. G., Bonnet, J., Vidal, R., ... \& Mégraud, F. (1997). Complex polysaccharides as PCR inhibitors in feces: Helicobacter pylori model. Journal of Clinical Microbiology, 35(4), 995-998.

Schrader, C., Schielke, A., Ellerbroek, L., \& Johne, R. (2012). PCR inhibitors-occurrence, properties and removal. Journal of Applied Microbiology, 113(5), 1014-1026.

Sousa, C., Brandão, M., Ribeiro, O., \& Cardoso, T. (2015). Communityacquired severe sepsis: a prospective cohort study. Open Journal of Internal Medicine, 5(03), 37.

Strasters, K. C., \& Winkler, K. C. (1963). Carbohydrate metabolism of Staphylococcus aureus. The Journal of General Microbiology, 33, 213 229.

Suaifan, G. A., Alhogail, S., \& Zourob, M. (2017). Rapid and low-cost biosensor for the detection of Staphylococcus aureus. Biosensors and Bioelectronics, 90, 230-237.

Velasco, D., del Mar Tomas, M., Cartelle, M., Beceiro, A., Perez, A., Molina, F., ... \& Bou, G. (2005). Evaluation of different methods for 
detecting methicillin (oxacillin) resistance in Staphylococcus aureus. Journal of Antimicrobial Chemotherapy, 55(3), 379-382.

Vincent, J. L. (2003). Nosocomial infections in adult intensive-care units. The Lancet, 361(9374), 2068-2077.

Warren, D. K., Liao, R. S., Merz, L. R., Eveland, M., \& Dunne Jr, W. M. (2004). Detection of methicillin-resistant Staphylococcus aureus directly from nasal swab specimens by a real-time PCR assay. Journal of Clinical Microbiology, 42(12), 5578-5581.
Weems Jr, J. J. (2001). The many faces of Staphylococcus aureus infection: recognizing and managing its life-threatening manifestations. Postgraduate Medicine, 110(4), 24-36.

Yue, H., Zhou, Y., Wang, P., Wang, X., Wang, Z., Wang, L., \& Fu, Z. (2016). A facile label-free electrochemiluminescence biosensor for specific detection of Staphylococcus aureus utilizing the binding between immunoglobulin $\mathrm{G}$ and protein A. Talanta, 153, 401-406.

Cite as/Attf şekli: Cetin, A., \& Koluman, A. (2021). Metisilin dirençli Staphylococcus aureus (MRSA) enfeksiyonu için hızlı uyarı sistemi. Front Life Sci $R T, 2(3), 75-84$. 